June 1993

\title{
Psychodynamic Contours of Post-Traumatic Stress Disorder
}

\author{
Noah D. Freedman, MD \\ Thomas Jefferson University Hospital
}

Follow this and additional works at: https://jdc.jefferson.edu/jeffjpsychiatry

Part of the Psychiatry Commons

Let us know how access to this document benefits you

\section{Recommended Citation}

Freedman, MD, Noah D. (1993) "Psychodynamic Contours of Post-Traumatic Stress Disorder," Jefferson Journal of Psychiatry. Vol. 11 : Iss. 2 , Article 16.

DOI: https://doi.org/10.29046/JJP.011.2.014

Available at: https://jdc.jefferson.edu/jeffjpsychiatry/vol11/iss2/16

This Article is brought to you for free and open access by the Jefferson Digital Commons. The Jefferson Digital Commons is a service of Thomas Jefferson University's Center for Teaching and Learning (CTL). The Commons is a showcase for Jefferson books and journals, peer-reviewed scholarly publications, unique historical collections from the University archives, and teaching tools. The Jefferson Digital Commons allows researchers and interested readers anywhere in the world to learn about and keep up to date with Jefferson scholarship. This article has been accepted for inclusion in Jefferson Journal of Psychiatry by an authorized administrator of the Jefferson Digital Commons. For more information, please contact: JeffersonDigitalCommons@jefferson.edu. 


\title{
Psychodynamic Contours of Post-Traumatic Stress Disorder
}

\author{
PSYCHOTHERAPY OF THE COMBAT VETERAN \\ Harvey J. Schwartz, M.D., Ed. \\ New York, Spectrum Publications, 1984 \\ Distributed by: Integrated Publishers, 195 McGregor St., \\ Manchester, NH 03102, 603-669-5933
}

Noah D. Freedman, M.D.

In Psychotherapy of the Combat Veteran, Harvey J. Schwartz, M.D. offers the reader an intellectually challenging but rewarding journey through a psychodynamic exploration of the "war neuroses." Though the concept of a post-traumatic stress disorder (PTSD) was noted by Dr. Schwartz to have occurred in the literature by 1978, and it was enshrined in the DSM III in 1980, the work in this volume lifts the veil of the purely descriptive approach to explore the psychodynamic contours of the topic. Dr. Schwartz has assembled many aspects of the literature including the history of traumatic neuroses, sleep research, psycho-pharmacology, group therapy, brief therapy, psychoanalytic psychotherapy, prevention, and an investigation of the effects of the broader social environment.

Schwartz frames the book with an excellent introductory chapter that sets out the volume's main tasks: (1) an investigation of the psychological effects of massive trauma, including the interaction of overwhelming external events with underlying infantile conflicts or fantasies; and (2) an exploration of what an effective "holding environment" may be for the sufferers of PTSD.

These tasks are accomplished with a fine collection of articles which review past literature and present original formulations. Transference and countertransference in work with severely traumatized patients are addressed by Shapiro and in two articles by Schwartz. Blitz and Greenberg postulate an approach to dream material related to concepts of self psychology. Most helpful to me were the abundant case examples in this volume, which provided vivid glimpses of the psychotherapeutic work. Those who have had some experience with trauma survivors and can appreciate the abstract nature of psychodynamic literature will be able to extract useful pointers for the direction and pitfalls in psychodynamic psychotherapy with sufferers of PTSD.

Dr. Schwartz presents several cases including a particularly moving study of a severely dissociated patient caught up in reliving an overwhelming traumatic experi-

Noah Freedman, M.D. is a PGY-IV resident in psychiatry at Thomas Jefferson University Hospital in Philadelphia. 
ence. He evocatively describes the countertransferential aspects of his work with this patient, who worked with mutilated bodies in the graves registry.

Throughout this volume, especially in the work of Drs. Schwartz and Blitz and Greenberg, it is made clear that a holding environment needs to be created in which the patient is able to work through these traumatic events and feelings and have the infantile conflicts they evoke worked through in the transference. Of course each treatment must be tailored to each patient, however, it seems clear that to avoid the past trauma is denigrating to the patients who often find themselves reliving it in the present. This leads to the necessity of abreactive work to allow all the feelings evoked into the treatment frame. Given that long-term psychotherapy is not economically feasible for the majority of trauma sufferers, Dr. Schwartz suggests cultural means, such as the mythology of the revered warrior, that may be used to create a symbolic environment which could welcome veterans back into the community.

Drs. Moses and Cohen, in a paper discussing Israeli military experience over four decades, delineate useful preventive measures as well as immediate, short-term, and long-term posttraumatic interventions.

The psychobiological research described in this 1984 volume has been partially superseded in recent years. Studies in the psychobiology of memory have led to greater awareness of how memory may be structured beyond the cognitive levels of the cerebral cortex. Specific chemical probes are now on the verge of elucidating more precise means for alleviating or provoking various aspects of PTSD. The dissociative aspects of flashbacks are being carefully described and provoked in experiments which indicate that individuals may be suffering from either a serotonergic or noradrenergic dysregulation $(1,2,3)$. Other neurotransmitters are also involved $(4,5,6)$.

Another weak point in this volume is that there is little discussion of the phenomenon of dissociation, other than as simply a defensive aspect of the ego. Recent work by Cardena (7) has demonstrated that trauma can directly provoke dissociative experiences in its victims. Spiegel has investigated the use of hypnosis (which he views as a controlled dissociation) to enable patients to gain mastery over traumatic dissociation (8).

Though an early contribution to the modern literature on trauma, this book offers many valuable insights into psychotherapeutic work with patients (not only combat veterans) who suffer from post-traumatic stress disorder. Dr. Schwartz presents complex, thought-provoking material with profound respect for those who still suffer the effects of wartime trauma.

\section{NOTES}

1. Bremner JD, Southwick SM, Brett E, Rosenheck RA, Fontana A, Charney DS: Increased dissociative states in PTSD. Presented at 1993 Convention, American Psychiatric Association, Symposium \#52

2. Krystal JH, Southwick SM, Karper LP, Bremner JD, Charney DS: The emerging neurobiology of dissociation. Presented at 1993 Convention, American Psychiatric Association, Symposium \#52 
3. van der Kolk BA, Levin P, Ducey C: Fluoxetine and integration of traumatic memories. Presented at 1993 Convention, American Psychiatric Association, Symposium \#52

4. van der Kolk BA, Fisler RE: The biological basis of post-traumatic stress. Primary Care; Clinics and Office Practice 1993; 20(2):417-32

5. Pitman RK, van der Kolk BA, Orr SP, Greenberg MS: Naloxone-reversible analgesic response to combat-related stimuli in posttraumatic stress disorder. A pilot study. Archives of General Psychiatry 1990; 47(6):541-4

6. van der Kolk BA: The compulsion to repeat the trauma. Reenactment, revictimization, and masochism. Psychiatric Clinics of North America 1989; 12(2):389-411

7. Cardena E, Spiegel D: Dissociative reactions to the San Francisco Bay earthquake of 1989. American J Psychiatry 1993; 150(3):474-8

8. Spiegel D: Hypnosis in the treatment of victims of sexual abuse. Psychiatric Clinics of North America 1989; 12(2):295-306 